\title{
Improvement of Quality, Interest, Critical, and Analytical Thinking Ability of Students through the Application of Research Based Learning (RBL) in Introduction to Stochastic Processes Subject
}

\author{
Atina Ahdika ${ }^{a}$ \\ aDepartment of Statistics, Universitas Islam Indonesia, \\ Jalan Kaliurang Km 14.5, Sleman Yogyakarta, Indonesia
}

The ability to think critically and analytically is one of the main competencies expected of a learning process in higher education institution, especially in science area. A scientist should be able to explore a problem, choose the appropriate method, obtain the solutions, and communicate their analysis correctly. To support these outcomes, we need appropriate method so that student's skills in scientific thinking can be realized. In this study we offered a method to improve the quality, interest, and student's ability to think critically and analytically through the implementation of Research Based Learning (RBL). This method trains the students to conduct research on an issue in real life. The object of the research is students majoring in Department of Statistics Islamic University of Indonesia taking the course Introduction to Stochastic Processes in second semester of the 2015/2016 academic year. The results indicate that around $89.41 \%$ of students were satisfied and interested in RBL learning system, the average scale of the student's final mark is 3.3 out of 4 , and $84.44 \%$ of students were able to conduct a research with scientific framework. We conclude that this learning method significantly improve student achievement and provide satisfaction and student interest in following the course.

KEYWORDS

Analytical, critical thinking, Introduction to Stochastic Processes, Research Based Learning
ARTICLE HISTORY

Received 17 October 2016 Revised 18 January 2017 Accepted 13 March 2017

\section{Introduction}

One of the expected outcomes of learning activities in an institution of higher education, especially in the fields of science, is the ability to think critically and analytically. Critical thinking, in simple language, is the ability to 
analyze and evaluate information (Duron et. Al, 2006). A person who thinks critically is able to explore a problem from the phenomena that occured in the environment, modeling the problem clearly, getting the right solution, and be able to effectively communicate the results of their analysis. One area of sciences that requires the graduates of having the skills is Statistics area. Snee (1993) in Ganio (2010) states that the education in the field of Statistics has traditionally focused on the development of knowledge and skills and it is assumed that students can create a value on the subject in the educational process, but this approach does not work. To overcome the weaknesses in traditional learning methods in Statistics area, it is required an appropriate method to be applied in classroom learning system. These methods are expected to attract the interest of students in the learning process and can practice the skills in exploring and analyzing a problem in the framework of a scientist.

In this study, we designed an appropriate learning method to train Statistics student's ability in critical and analytical thinking. The object of the research is students majoring in Department of Statistics Islamic University of Indonesia who take the course Introduction to Stochastic Processes in class A and D in the second semester of the 2015/2016 academic year. This subject is one of the difficult courses because of the nature of the material is conceptual, but a potential land for research study, this reason which prompted the author to choose the course Introduction to Stochastic Processes as the research objects. The course Introduction to Stochastic Processes is an institutional and compulsory subject given in the 6th semester at the Department of Statistics Faculty of Mathematics and Natural Sciences, Islamic University of Indonesia. This course is a subject that emphasizes statistical mathematical framework to model and solve problems associated with the random process that involves time. One of the goals / learning outcomes expected from this course is to master the basic concepts of statistical science and methodology (methods and models) statistics that can be used in solving problems in the field of disaster management or business, industry, and social. However, because its material is likely conceptual and quite difficult to understand, the application of the material taught in this course is still rarely used, in contrast to the other statistics subjects that are applicable. This resulted in the lack of interest of students to learn more about stochastic processes. As a result, it is very rare to find the students who choose the method of the course Introduction to Stochastic Processes both in their research and their final project.

In addition to the difficulties in terms of materials and applications, problems also arise in terms of teaching methods and evaluation. In this course, the teaching methods conducted in previous years until the 2013/2014 school year is the traditional method that are lecturers deliver lecture materials, giving the example problems, discuss the exercises, and provide an evaluation to students in the form of assignments, quizzes, midterm and final exam. With this method, students are only glued on the matter and the case examples given in the classroom, so it is often found the case that students are not able to solve the problems of different types to those taught in the classroom, despite using the same method. In its development, in the academic year 2014/2015, we have been applied the other teaching methods in which each after two meetings were used 
to provide teaching materials, conducted a special discussion which discusses the problems presented in the form of stories and completed within the respective groups each consisting of 5-6 people. Because members are pretty much in one group, this teaching method only produces optimal understanding of the material to students who have more capabilities among others. It is proven by the achievement of learning outcomes of students who do not give a significant increase. The average value of students in the course Introduction to Stochastic Processes in the last five years cannot reach the scale of 3 out of 4 . It is unfortunate, considering this course is one of the subjects which able to train the analytical framework as a Statistics student.

One way that is effective in increasing student interest and ability in understanding a lecture material is by applying the method of Problem Based Learning (PBL) (Ali, 2009). This method emphasizes the application of theory to the cases encountered significantly so that students know to what extent the theoretical study can be applied to real life. PBL method is an instructional model that is oriented on authentic problems and focuses on the challenges that make the students can think (Arends, 2008). Oon Seng Tan (2003) in Safryadi et al (2013) outlined that some PBL cases can provide solutions to the problems by utilizing knowledge from various fields of study and the topics being taught. Thus, the student's ability to solve problems by PBL, validly can also improve their understanding of material course (Safryadi et al, 2013). To train the student's ability to think systematically, PBL method was later developed into a Research Based Learning (RBL) method. RBL method emphasizes learning through research done by the students. Research is an important tool to improve the quality of learning that consists of several components such as background, procedures, implementation of the results of research and discussion, as well as the publication of research results (Hafsah, 2015). This method can help students to practice the skills of digging a problem, choose the appropriate method to solve problems, and communicate the results of their analysis in the form of research publication.

Based on these considerations, then came the idea to elaborate a teaching method that combine PBL method with research and literature review deeper in the expansion of science concepts through the application of stochastic methods using Research Based Learning (RBL). This method also requires students to be willing to practice their critical thinking and reading the literature related to the application and expansion of the material taught in the course Introduction to Stochastic Processes outside the classroom more independently and to train students to write down the results of his thinking into form of scientific articles. This method is expected to improve the learning interest of students towards the courses Introduction to Stochastic Processes through experience on the research, to improve the quality, interest, and ability to think critically and analytically students through excavation and problem resolution methods of stochastic field which can be found in the real life. 


\section{Literature Review}

In accordance with their duties, every university is required to do their tasks, one of them is in terms of research. Research, creation, and dissemination are the basis for the operation of the research-based university. The purpose of the learning method of Research Based Learning (RBL) is to help students build a strong intellectual and connects the advancement of research with the student learning process itself (Alison, accessible from www.griffith.edu.au/gihe). Gains obtained by a student with those learning methods include (Alison, accessible from www.griffith.edu.au/gihe):

1. Embed the values of discipline, practice, and ethics in student itself

2. Linking the lecture materials with the findings of the study

3. Improve students understanding in the contribution of the lecture material to the problems in society

4. Develop and enrich the skills and abilities of students include:

a. Generic skills such as critical and analytical thinking, searching information, and evaluation, as well as problem solving

b. The ability to conduct and evaluate a research that assist in personal and professional lives of students

5. Provide ample opportunities in the learning process with the approach of the investigation based on the experiences and methods acquired by the students in classroom

Research Based Learning (RBL) is based on the philosophy of constructivism that includes four aspects, namely: learning that build student understanding, learning by developing prior knowledge, learning is a process of social interaction, and meaningful learning is achieved through real experience (Widayati et al, 2010). Thus, this learning method emphasizes the process of formulation of the problem, problem solving, and communication of the results of the settlement of the problem (research) to a wide audience. Those aspects are in line with one of the basic principles that underlie effective learning which is students must learn to monitor, evaluate, and adjust their approaches to learning to become self-directed learners (Eberly Center for Teaching Excellence, accessible from http://www.cmu.edu/teaching/). Research helps students to monitor and evaluate their own performance because all processes in the research are conducted by themselves, either individually or in groups.

Healey et al (2014) designed the curricula which can help individual staff, course teams, and whole institutions consider ways of strengthening students' understanding of and through research. The curricula consist of four ways:

1. Research-led: learning about current research in the discipline. The curriculum focus is to ensure that what students learn clearly reflects current and ongoing research in their discipline. This may include research done by staff teaching them.

2. Research-oriented: developing research skills and techniques. The curriculum focus is on developing students' knowledge of and ability to carry out the research methodologies and methods appropriate to their discipline(s).

3. Research-based: undertaking research and inquiry. The curriculum focus is on ensuring that as much as possible the student learns in research and or inquiry mode (i.e. the students become producers of knowledge 
not just consumers). The strongest curricula form of this is in those special undergraduate programmes for selected students, but such research and inquiry may also be mainstreamed for all or many students.

4. Research-tutored: engaging in research discussion. The curriculum focus is on students and staff critically discussing research in the discipline as, for example, in many seminar-based courses.

Figure 1 shows the model of the curricula designed by Healey (2014).

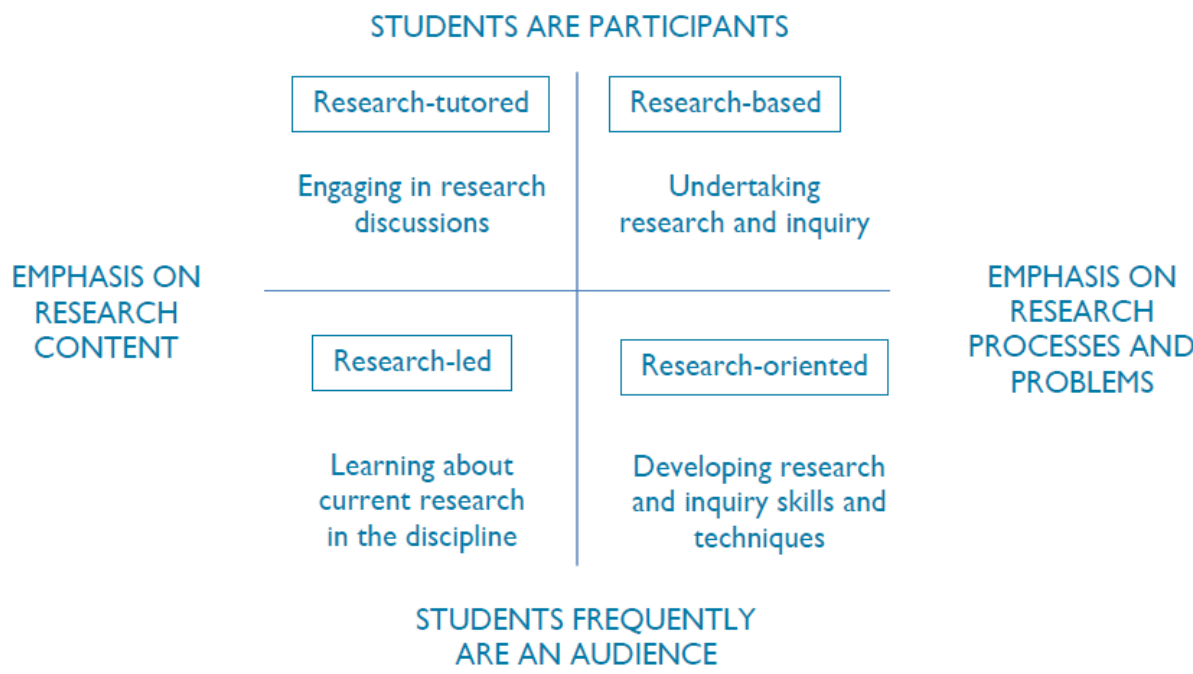

Source: Developing research-based curricula in college-based higher education (Healey et al, 2014)

Figure 1. Curriculum design and the research-teaching nexus

In developing the ability of students to think critically and analitically, we can use one of the curriculum adjusted to the aim of the course. First curricula may appropriate be used if the teacher wants to teach the students how to linking the course with the current research. The second curricula can be chosen if the teacher wants to develop students' skill on the research methodologies and choose the most appropriate method with their problems. If the teacher wants to train the students to conduct a research by their own effort and ability, then the third curricula is the best one to be used. Last curricula can be used if the teacher wants to nurture a culture of discussion among students and staff about the research in the discipline.

Healey (2014) is also derived four strategies for engaging students with research and inquiry within courses and programmes. Strategy one, develop students' understanding of the role of research and inquiry in their discipline. This strategy can be done by developing curriculum which bringing out current or previous research in the discipline and developing students' awareness of the nature of research. Strategy two, develop students' abilities to carry out research by developing student involvement in research. Strategy three, progressively develop students' understanding. Strategy four, manages students' experience of 
research, evaluate students' experience of research, and feed that back into the curriculum.

Dr. Alison Green in his article entitled "GIHE Good Practice Guide on Research-Based Learning" (accessible from www.griffith.edu.au/gihe), lays out a successful strategy in linking teaching with research. The successful strategies include (Alison, accessible from www.griffith.edu.au/gihe):

1. Draw on personal research in designing learning system

a. Combining current research directly into the curriculum as a whole focus of the lecture material

b. Referring to the personal experience to overcome the problem of 'real world' on the lecturer's research as examples / illustrations to help students in understanding the ideas, concepts, and theories

c. Describing the practices, values, and ethics of lecturer's discipline by encouraging all students to discuss their research

2. Placing the latest research in the field in a historical context in the classroom teaching

a. Contextualise discussions of current research findings with reference to several theories that have been discredited from the past and stimulating debate at the present

b. Generating the temporary nature of a science and its dynamics, and develop it with a historical perspective that shows how current policies and practices are constantly evolving from previous practice

3. Designing learning activities on issues of contemporary research Instruct students to explore cutting-edge research problem or propose a solution to the problems in real life based on their knowledge of fundamental disciplines. These activities included instruct students to:

a. Investigate reports of current research status by comparing the results of the learning report with the results of the official report

b. Analyzing the methods and arguments presented in the article in a journal that shows the findings of the present

c. Doing a small scale literature review that leads to conclusions about the current state of knowledge and the following questions that may arise

4. Teaching research methods, techniques, and skills explicitly in the teaching program

a. Build students' understanding of research methodology during laboratory classes

b. Designing the lectures on research methods that provide opportunities for students to apply their research capabilities to authenticate the research problem

c. Designing assessment tasks within the subject matter that gives students the opportunity to learn different methods and skills relating to issues of contemporary research

5. Developing research activities / small research for undergraduate students

a. Instruct students to analyze data from the 'real world' research project 
b. Provide research questions to students that require them to do small-scale literature review, decide appropriate methods, collect data, write down the results, and draw conclusions

c. Offers lectures that focus on large projects that utilize research skills and discipline of the knowledge gained from the previous semester

6. Engaging students in research projects in the study program

a. Providing students with self-contained projects in larger projects

b. Organize students to act as a research assistant for students with a higher level or for faculty members

c. Arrange visits to university research centers

7. Encourage students to feel part of a research culture of Department

a. Inform the undergraduate students about areas of research interest in Department and staff member in which they are studying

b. Referring to areas of interest and achievements of colleagues, and if possible, invite them to provide material about their jobs to students

c. Encourage undergraduate and graduate students to attend research seminars

8. Infuse teaching with the values of researchers

Encouraging students to understand and aspire to the values of a researcher like objectivity, respect for evidence, respect the views of other researchers, tolerance of ambiguity, and have analytical rigour, by:

a. Modeling the values of researchers in the interaction in the classroom

b. Discussed about the process to be followed before the researchers published their work and the number of revisions that are usually involved

c. Providing structured learning experiences that require students to develop these values, such as providing research articles presenting opposing arguments on the same topic and ordered students to analyze the validity of the study and draw conclusions.

In implementing research-based learning, there are some activities have to be done by students. In general, student activities in research process include (Tremp, 2010):

1. Formulating a general question

2. Overview on research-literature

3. Defining the question

4. Planning research activities, clarifying methods/methodologies

5. Undertaking investigation, analyzing data

6. Interpretation and consideration of results

7. Report and presentation of results

The activities accommodate the capability training to students in exploring the problem, choosing the best method to solve the problem, and also communicating their analysis result to the audience.

Based on the literature review of the principles of this research based learning, the researchers designed a method of teaching and evaluation using RBL method which aims to improve the quality, interest, and ability to think critically and analytically students in the course Introduction to Stochastic Processes. 


\section{Research Methodology}

\section{Design of Learning Method}

Design of the learning method is a Research Based Learning (RBL) method by adapting some of successful strategies that have been outlined by Dr. Alison Green in the previous section and using the third curriculum design of Healey et al (2014). This method consists of five major concepts as follows:

1. Presenting Teaching Materials

Teaching materials are given in the first 11 meetings. Inside each meeting, the lecturer deliver the teaching material, discuss case study, and exercises, as well as giving assignments and midterms exam that must be completed by the students.

2. Implementation of Small Research

Students were divided into small groups to carry out small-scale research. The groups can conduct a research using data obtained from the survey / field studies, making the questionnaire, taking data from an agency / particular institution, or using simulation data by applying methods of analysis which they learned in the course Introduction to Stochastic Processes.

3. Execution of Lecturer Consultation and Research Presentation

To monitor the progress of the student's research, the lecturer open a consultation sessions both inside and outside the classroom and conduct a presentation of research that includes presentation of ideas and presentation of research progress on the rest of the lecture.

4. Organizing a Book of Student's Research Article

The results of student's research are written in the form of scientific articles. Student research articles are then collected and recorded for the purpose of making it as a reference and reading material for the next generations of students to enrich the knowledge of students about the material learned in the course Introduction to Stochastic Processes and their application in real life.

5. Selection for The Best Article for Publication

Once the research is completed, the research is assessed from various aspects, including in terms of writing techniques and in terms of ideas and analyzing data. The best article from each class then selected and developed for inclusion in the scientific publication activities, i.e. seminars / scientific conferences.

In general, the design of the learning method is presented in Figure 2.

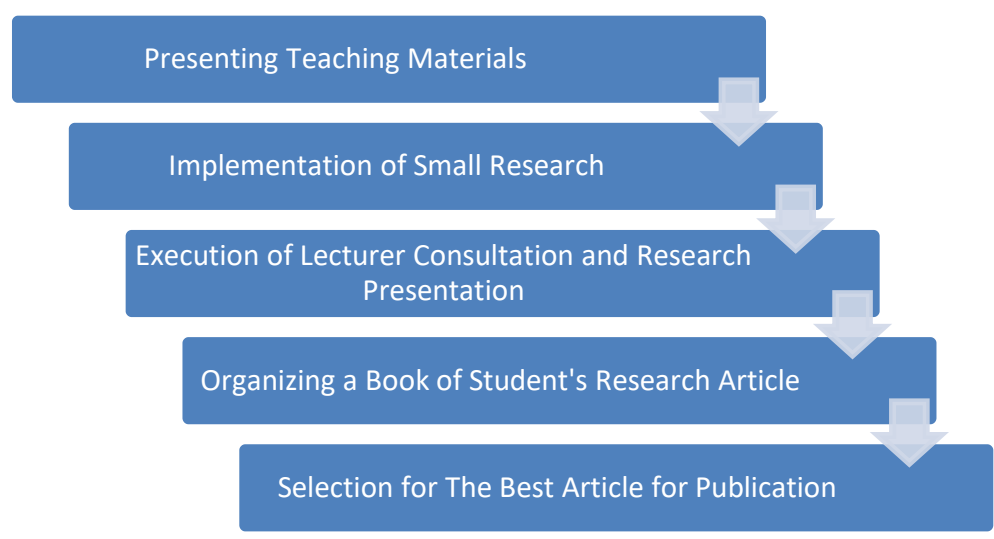

Figure 2. Design of learning method 
As for the implementation phase of learning and evaluation methods based on this research are presented in Table 1

Table 1. Implementation Phase of Learning Method

\begin{tabular}{|c|c|c|}
\hline No & Implementation Phase & Description of Activities \\
\hline 1. & $\begin{array}{l}\text { Providing of Supporting } \\
\text { Material Class }\end{array}$ & $\begin{array}{l}\text { Provision of libraries; text books and scientific } \\
\text { journals related. }\end{array}$ \\
\hline 2. & Preparation of Program & $\begin{array}{l}\text { a. Making the groove lecture } \\
\text { b. Making teaching material in one semester } \\
\text { c. Scoping study } \\
\text { d. The collection of scientific writings for } \\
\text { example for students. } \\
\text { e. Making the matter of pre-test as part of the } \\
\text { identification of the ability of each student. } \\
\text { f. Making the template of student articles. } \\
\text { g. Making the plan of implementation } \\
\text { research presentations } \\
\text { h. Making the format and criteria used for } \\
\text { group presentations. } \\
\text { i. Making the program evaluation form. }\end{array}$ \\
\hline 3. & Implementation & $\begin{array}{l}\text { a. The division of the research group } \\
\text { b. The provision of teaching materials } \\
\text { c. Implementation of small research } \\
\text { d. Implementation of the presentation of ideas } \\
\text { and research progress } \\
\text { e. Selection of the best research article } \\
\text { f. Collection and archiving student scientific } \\
\text { articles } \\
\text { g. Implementation of the participation of the } \\
\text { best scientific articles of each class in a } \\
\text { national seminar, conference, or delivery to } \\
\text { the journal at a suitable scale. }\end{array}$ \\
\hline 4. & $\begin{array}{l}\text { Monitoring and Evaluation } \\
\text { Phase }\end{array}$ & $\begin{array}{l}\text { a. Assessment of the assignments, exams, and } \\
\text { student research } \\
\text { b. Assessment results of evaluation of } \\
\text { students through questionnaires }\end{array}$ \\
\hline 5. & $\begin{array}{l}\text { Program } \\
\text { Phase }\end{array}$ & $\begin{array}{l}\text { The development program is based on the } \\
\text { evaluation of the results of the implementation } \\
\text { of the program for one semester. }\end{array}$ \\
\hline
\end{tabular}

\section{Design of Evaluation and Program Performance Indicators}

Evaluation of student research consists of three major parts which are further subdivided into a number of research components, namely:

a. Assessment of the skills of digging a problem and choose the appropriate method. Assessment in this section is further divided 
into two points, namely the preliminary assessment and the theoretical basis as well as a bibliography.

b. Assessment of the ability to solve problems that have been formulated. Assessment in this section taken from the value of the analysis and discussion of students in the articles they made.

c. Assessment of the ability to present and communicate the results of research. Assessment in this section is divided into two points that is assessment on the part of the abstract and conclusions.

The division of the assessment in general is shown in Table 2

Table 2. Component of the Assessment for the Research

\begin{tabular}{|c|c|c|c|c|}
\hline No. & Skills & $\begin{array}{l}\text { Component of the } \\
\text { Assessment }\end{array}$ & Score & $\begin{array}{c}\text { Total } \\
\text { Score for } \\
\text { Each Skill }\end{array}$ \\
\hline \multirow[t]{2}{*}{1.} & $\begin{array}{lr}\text { Skills in } & \text { exploring } \\
\text { problems } & \text { and }\end{array}$ & $\begin{array}{l}\text { Introduction and } \\
\text { Theoretical Basis }\end{array}$ & $0-20$ & \multirow[t]{2}{*}{$0-30$} \\
\hline & $\begin{array}{l}\text { choosing the rignt } \\
\text { method }\end{array}$ & Reference & $0-10$ & \\
\hline 2. & $\begin{array}{l}\text { Skills in solving the } \\
\text { problem which has } \\
\text { been formulated }\end{array}$ & $\begin{array}{l}\text { Result } \\
\text { Analysis }\end{array}$ & $0-40$ & $0-40$ \\
\hline \multirow[t]{2}{*}{3.} & Skills in presenting & Abstract & $0-15$ & \multirow[b]{2}{*}{$0-30$} \\
\hline & $\begin{array}{l}\text { and communicating } \\
\text { the result of the } \\
\text { research }\end{array}$ & Conclusion & $0-15$ & \\
\hline \multicolumn{3}{|c|}{ Total } & $0-100$ & $0-100$ \\
\hline
\end{tabular}

For the assessment of the research, the score then converted into a scale of 100 for each type of skills and then converted again into the index value of the end. The conversion is done in the following way

$$
\text { Mark }=\left(\frac{\text { score for } i-\text { th skill }}{\text { total score for each skill }}\right) \cdot 100
$$

Researcher, in this case is the lecturer, providing benchmark values above B to declare the student is able to explore the problem, choose the appropriate method, solve problems, and communicate the results of its analysis. Assessment result of this research in addition is used to assess student's ability to think critically and analytically, it is also used as one component of the final assessment of student learning outcomes. The score weighting of each component of the assessment are presented in Table 3 
Table 3. Score Weighting for Final Mark

\begin{tabular}{clc}
\hline No. & \multicolumn{1}{c}{ Component of the Assessment } & Weight \\
\hline 1. & Exercise and Quiz & $30 \%$ \\
\hline 2. & Midterm Exam & $30 \%$ \\
\hline 3. & Research Article & $40 \%$ \\
\hline & Total & $100 \%$ \\
\hline
\end{tabular}

While the final index value is as shown in Table 4.

Table 4. Final Index Value

\begin{tabular}{cc}
\hline Index Category & Score \\
\hline $\mathrm{A}$ & $80-100$ \\
\hline $\mathrm{A}^{-}$ & $77.50-79.99$ \\
\hline $\mathrm{A} / \mathrm{B}$ & $75.00-77.49$ \\
\hline $\mathrm{B}+$ & $72.50-74.99$ \\
\hline $\mathrm{B}$ & $70.00-72.49$ \\
\hline $\mathrm{B}^{-}$ & $67.50-69.99$ \\
\hline $\mathrm{B} / \mathrm{C}$ & $65.00-67.49$ \\
\hline
\end{tabular}

\begin{tabular}{cc}
\hline Index Category & Score \\
\hline $\mathrm{C}+$ & $62.50-64.99$ \\
\hline $\mathrm{C}$ & $60.00-62.49$ \\
\hline $\mathrm{C}-$ & $55.00-59.99$ \\
\hline $\mathrm{C} / \mathrm{D}$ & $50.00-54.99$ \\
\hline $\mathrm{D}+$ & $45.00-49.99$ \\
\hline $\mathrm{D}$ & $40.00-44.99$ \\
\hline $\mathrm{E}$ & $<40.00$ \\
\hline
\end{tabular}

In addition, to assess the quality and interest of students towards learning program offered, we also made a questionnaire to be filled out by the students. Materials of the evaluation are divided into four sections, each of which consists of five questions consist of the material and media lectures, course lecturer, the implementation of the learning program, and assessment systems. Questionnaires were developed and tested for validity and reliability. Validity test is done by calculating the Pearson correlation and performed on each of the question, then the results are compared with the $r$-table. Formula for the Pearson correlation is as follows:

$$
r=\frac{n\left(\sum x y\right)-\left(\sum x\right)\left(\sum y\right)}{\sqrt{\left(n \sum x^{2}-\left(\sum x\right)^{2}\right)\left(n \sum y^{2}-\left(\sum y\right)^{2}\right)}}
$$

where

$r$ : correlation coefficient

$x$ : item score

$n$ : size of sample

$y$ : total score

If $r$-table $<r$-count, then the question is valid

If $r$-table $>r$-count, then the question is not valid

By using a 0.05 level of significance with the number of the item in question is 20 and students who filled out the questionnaire as many as 59 people, then the $r$-table was used is 0.2612 (obtained by interpolation). As for the reliability test, we used Cronbach's alpha formula: 


$$
r=r k /(1+(k-1) r)
$$

where

$k:$ the number of items to be considered

$r$ : the average correlation between item

Value level of reliability Cronbach's alpha can be seen in Table 5 (Hair et al., 2010)

Table 5. Cronbach's Alpha Level of Reliability

\begin{tabular}{cc}
\hline Cronbach's Alpha Score & Level of Reliability \\
\hline $0.0-0.20$ & Less Reliable \\
\hline$>0.20-0.40$ & Rather Reliable \\
\hline$>0.40-0.60$ & Quite Reliable \\
\hline$>0.60-0.80$ & Reliable \\
\hline$>0.80-1.00$ & Very Reliable \\
\hline
\end{tabular}

Form of evaluation made in a Likert scale of 1 through 4 with details of values as follows:

1. Very poor

2. Not good

3. Good

4. Very good

Of the four scales, the researchers provide a reference that students are considered as satisfied and interested in learning programs if the score filled is 3 or above, while for the value below 3 are considered less satisfied and less interested. Results of validity and reliability test (with a 0.05 significance level) of the questionnaires were made after invalid items excluded are as follows 
Table 6. Validity and Reliability Result

\begin{tabular}{|c|c|c|c|c|}
\hline & Component of the Question & $r$-table & $r$-count & Validity \\
\hline \multicolumn{5}{|c|}{ A. Material and Media Lectures } \\
\hline 1. & Suitability of the material with the planning & 0.2612 & 0.321 & Valid \\
\hline 2. & $\begin{array}{l}\text { Material lectures help students to develop } \\
\text { skill of critical and analytical thinking of the } \\
\text { scientific fields related to probability theory }\end{array}$ & 0.2612 & 0.398 & Valid \\
\hline & $\begin{array}{l}\text { Students interested in conducting research } \\
\text { using the course material has been taught }\end{array}$ & 0.2612 & 0.487 & Valid \\
\hline 4. & $\begin{array}{l}\text { Students get lectures and examples of } \\
\text { materials research easily }\end{array}$ & 0.2612 & 0.560 & Valid \\
\hline \multicolumn{5}{|c|}{ B. Course Lecturer } \\
\hline 1. & Punctuality of lecturers in teaching & 0.2612 & 0.361 & Valid \\
\hline 2. & $\begin{array}{l}\text { Readiness and clarity of the lecturers in } \\
\text { teaching }\end{array}$ & 0.2612 & 0.461 & Valid \\
\hline & $\begin{array}{l}\text { Mastery of the lecturers to lecture the } \\
\text { material being taught }\end{array}$ & 0.2612 & 0.518 & Valid \\
\hline 4. & $\begin{array}{l}\text { Willingness of the lecturers in serving } \\
\text { questions or comments of students }\end{array}$ & 0.2612 & 0.413 & Valid \\
\hline \multicolumn{5}{|c|}{ C. Implementation of the Learning Program } \\
\hline & $\begin{array}{l}\text { Lectures program (provision of material and } \\
\text { execution of research) provide comfortable } \\
\text { and attractive learning environment for } \\
\text { students }\end{array}$ & 0.2612 & 0.589 & Valid \\
\hline & $\begin{array}{l}\text { Students are satisfied with the learning } \\
\text { program }\end{array}$ & 0.2612 & 0.535 & Valid \\
\hline 3. & $\begin{array}{l}\text { Students are able to explore problems to a } \\
\text { research related to the course being taught }\end{array}$ & 0.2612 & 0.456 & Valid \\
\hline 4. & $\begin{array}{l}\text { Students are able to determine the best } \\
\text { method of issues that have been excavated }\end{array}$ & 0.2612 & 0.622 & Valid \\
\hline & $\begin{array}{l}\text { Benefits of discussion in the lecture to the } \\
\text { student's understanding of the lecture } \\
\text { material and research assignments }\end{array}$ & 0.2612 & 0.488 & Valid \\
\hline \multicolumn{5}{|c|}{ D. Evaluation System } \\
\hline & $\begin{array}{l}\text { Suitability of the assignments and exams } \\
\text { with the lecture material }\end{array}$ & 0.2612 & 0.591 & Valid \\
\hline 2. & $\begin{array}{l}\text { Suitability of the percentage of each } \\
\text { component of the assessment to the work } \\
\text { load assignments, exams, and research }\end{array}$ & 0.2612 & 0.455 & Valid \\
\hline 3. & $\begin{array}{l}\text { The basis for assigning value and objectivity } \\
\text { of lecturers in the assessments }\end{array}$ & 0.2612 & 0.503 & Valid \\
\hline & $\begin{array}{l}\text { Clarity of the questions in assignments, } \\
\text { tests, and an explanation for doing research }\end{array}$ & 0.2612 & 0.590 & Valid \\
\hline 5. & $\begin{array}{l}\text { The estimated mark to be obtained for this } \\
\text { course }\end{array}$ & 0.2612 & 0.474 & Valid \\
\hline
\end{tabular}


Based on the results of validity and reliability test above, all of the item in question except for question number 5 in part $\mathrm{A}$ and question number 5 in part B have been valid since the value of the $r$-table $<r$-count for each question. While the value of Cronbach's alpha is 0.862 so this questionnaire included into the level of very reliable.

In general, in order to compare the results from RBL method compared to the conventional method, the following are indicators of the performance of programs designed

Table 7. Performance Indicators of the Program

\begin{tabular}{|c|c|c|}
\hline \multicolumn{3}{|c|}{ No. Material of Evaluation } \\
\hline 1. & $\begin{array}{l}\text { The availability of a. } \\
\text { student learning media } \\
\text { b. } \\
\text { c. }\end{array}$ & $\begin{array}{l}\text { There are teaching materials prepared by the } \\
\text { lecturer } \\
\text { The availability of new textbooks } \\
\text { The availability of Book of Student's Research } \\
\text { Article }\end{array}$ \\
\hline 2. & Value of small research 10 & $\begin{array}{l}00 \% \text { of students obtained the value of small research } \\
\text { article and presentation) } \geq 80\end{array}$ \\
\hline 3. & Final mark & he average of the final mark of students $>2.8$ \\
\hline 4. & Student's quality & $\begin{array}{l}60 \% \text { of students can distinguish and select the } \\
\text { method suitable with their research and able to } \\
\text { explain and answer questions that arise during a } \\
\text { presentation. This measurement is obtained from } \\
\text { the presentation of scientific work student } \\
\text { assessment. } \\
\text { The best article from each class is published in } \\
\text { the proceedings of seminars, conferences, or } \\
\text { scientific journals. }\end{array}$ \\
\hline & $\begin{array}{l}\text { Student interest } \\
\text { satisfaction }\end{array}$ & $\begin{array}{l}0 \% \text { of students were satisfied and had an interest in } \\
\text { he material being taught in the course Introduction } \\
\text { o Stochastic Processes which obtained from the } \\
\text { ssessment of program evaluation form. }\end{array}$ \\
\hline
\end{tabular}

\section{Result and Analysis}

Implementation of research based learning program in one semester goes as follows; lecturers give a lecture material consisting of six chapters done during 11 meetings. There are 15 groups in the class $\mathrm{A}$ and 18 groups in class D, with each group has a member of each of the two people. Some of groups began working on his research after the material lecture completed to deliver, but some groups began working after the midterm exam. The lecturer consultation in a class was conduct at $12^{\text {th }}$ and $13^{\text {th }}$ meeting. The research activities of each group are documented in a log-book.

During the course progresses, after the material is completed to be given, the discussion has been held to discuss the issues of what can be appointed as student research materials. This discussion is one of the implementations of the 
active learning of students so that each student can express ideas and opinions, especially relating to the research process.

At the last meeting, a presentation of ideas was conducted. The presentation aims to convey the research idea upon by each group and discuss them with other groups so that other groups can provide suggestions and opinions for research to be conducted by each group. Then at week 15 (outside of lecture hours), we agreed on an additional meeting to discuss the progress of each group so that the lecturer can control the course of the study. Figure 3 shows the activities of presentation of ideas and research progress of students.

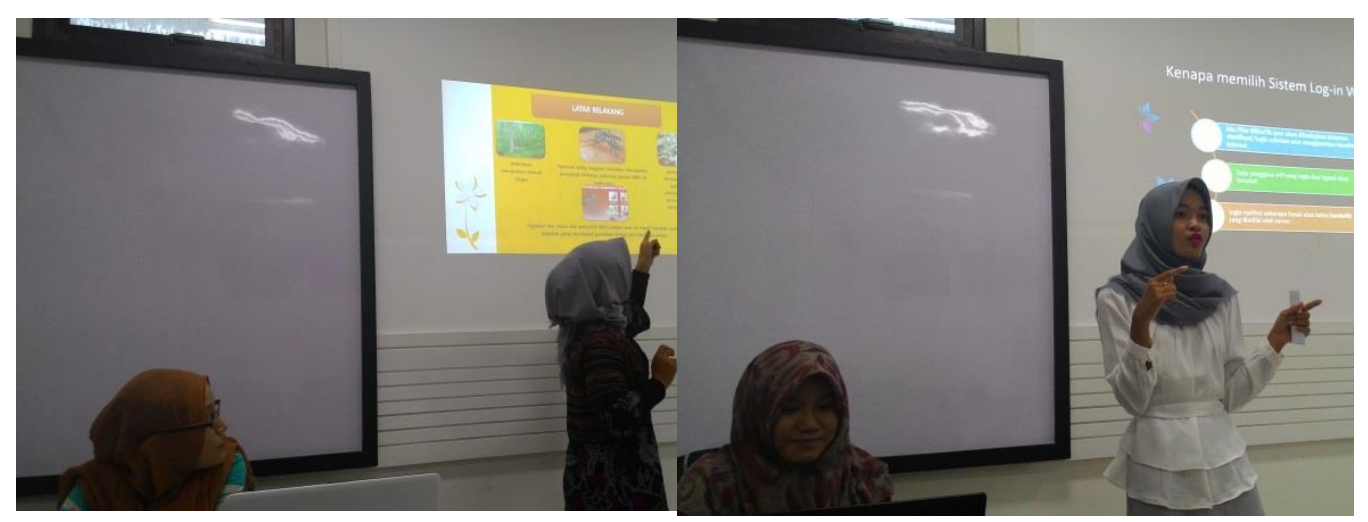

Figure 3. Presentation of ideas and progress of student research

For the implementation of small research, most of the group's own research data by collection (primary data), although on a small scale. Table 8 shows an example of the student research titles and types of data based on its source.

Table 8. Examples of Student Research Title

\begin{tabular}{clll}
\hline No. & \multicolumn{4}{c}{ Research Title } & Data Source \\
\hline 1. & Implementation of Naïve Bayes Algorithm and & Secondary Data \\
Discrete Markov Chain to Predict the Patient & \\
Status and State Transition Probability for & \\
Patients with Cervical Cancer in Hospital Dr. \\
Moewardi Surakarta 2014
\end{tabular}


Based on the results of student research, assessment is made according to the design in Table 2. The average results of student research assessment for each skill shown in Figure 4

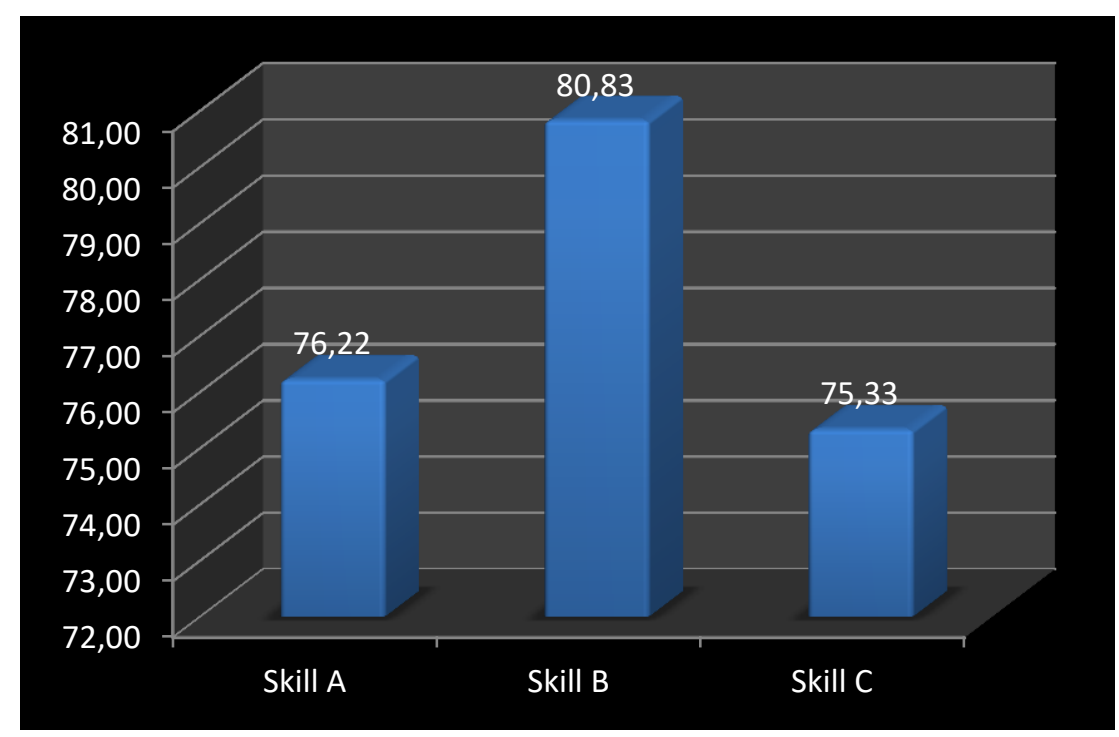

Figure 4. Result of student research

where

- Skill A: Skills in exploring problems and choosing the right method

- Skill B: Skills in solving the problem which has been formulated

- Skill C: Skills in presenting and communicating the result of the research

The average value of student's research in the form of index value for each skill and the percentage of students who are considered capable of having those skills are shown by Table 9 .

Table 9. Index Value of Student's Research

\begin{tabular}{clccc}
\hline No. & Type of Skill & Score & Index Value & $\begin{array}{c}\text { Percentage of Students } \\
\text { Considered as "Capable" }\end{array}$ \\
\hline 1. & Skill A & 76.22 & A/B & $73.33 \%$ \\
\hline 2. & Skill B & 80.83 & A & $100 \%$ \\
\hline 3. & Skill C & 75.33 & A/B & $80 \%$ \\
\hline & Average & 77.46 & A/B & $84.44 \%$ \\
\hline
\end{tabular}

Table 9 shows that the average skills of the students in doing research worth A/B. This means that the average student skills in doing research predicate fairly good value. While the average percentage of students who are considered able to explore the problem, select the method, solve problems, and communicate the results of the study amounted to $84.44 \%$. That is, from a total of 33 groups, about 28 groups deemed able to perform a series of research well. 
To assess the results of the overall study, the three components of the skills acquired are summed and the average value of each class study as follows:

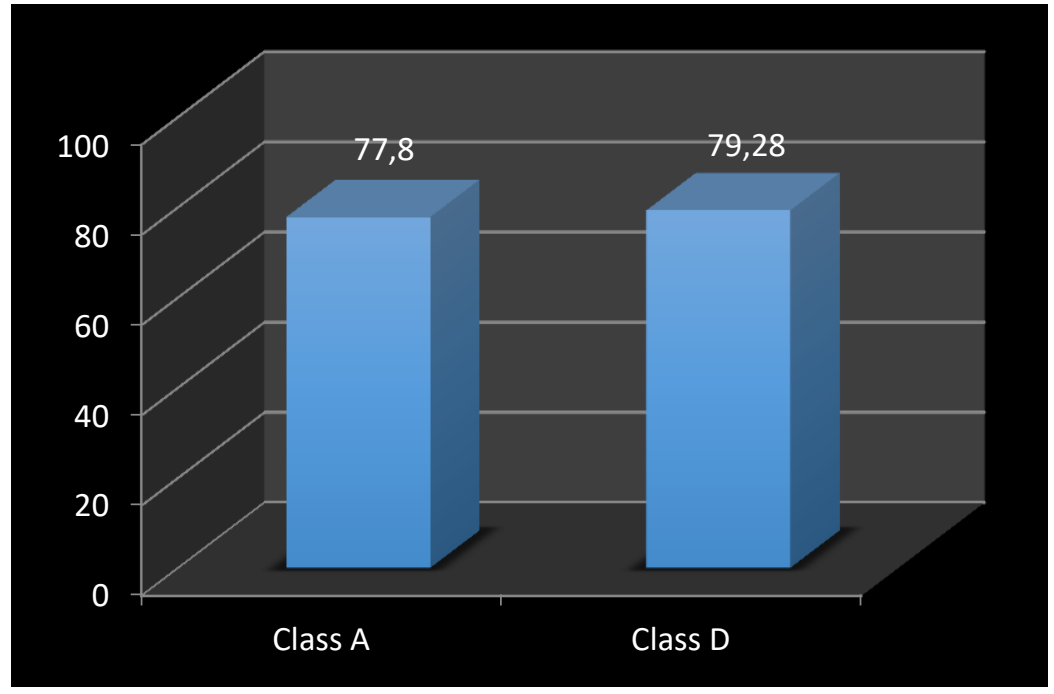

Figure 5. The average value of student's research

From Figure 5, it can be seen that the average value for the entire student research the for all types of skills is 77.8 for class A and 79.28 for class D, or an average of 78.54 for both classes. Meanwhile, when converted into the form of the index value, the average value of student's research in total is predicated as $\mathrm{A}^{-}$.

Furthermore, the values of the research are combined with other assessment components, such as assignments, quizzes, and UTS, according to Table 3 to obtain the student's final grades.

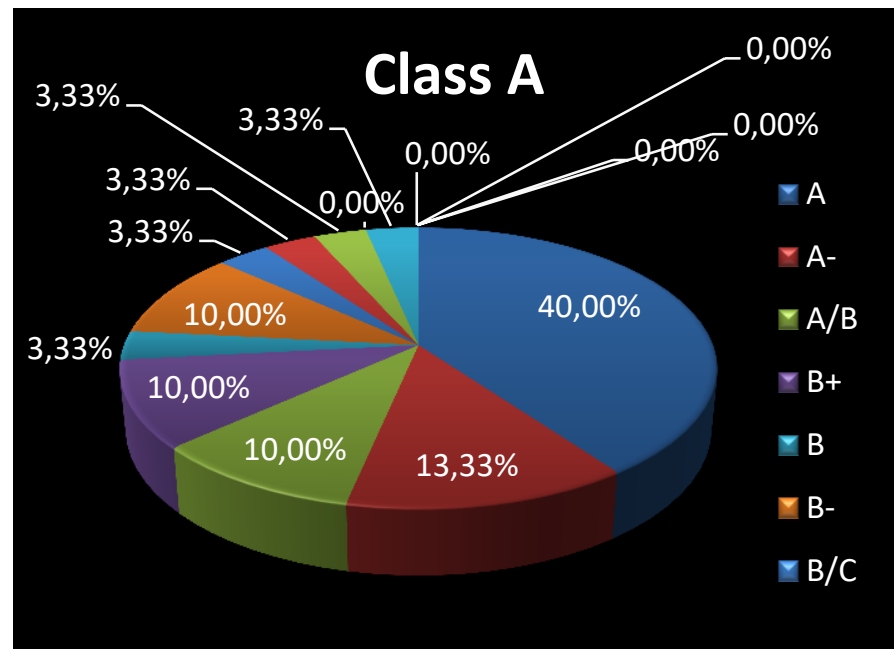



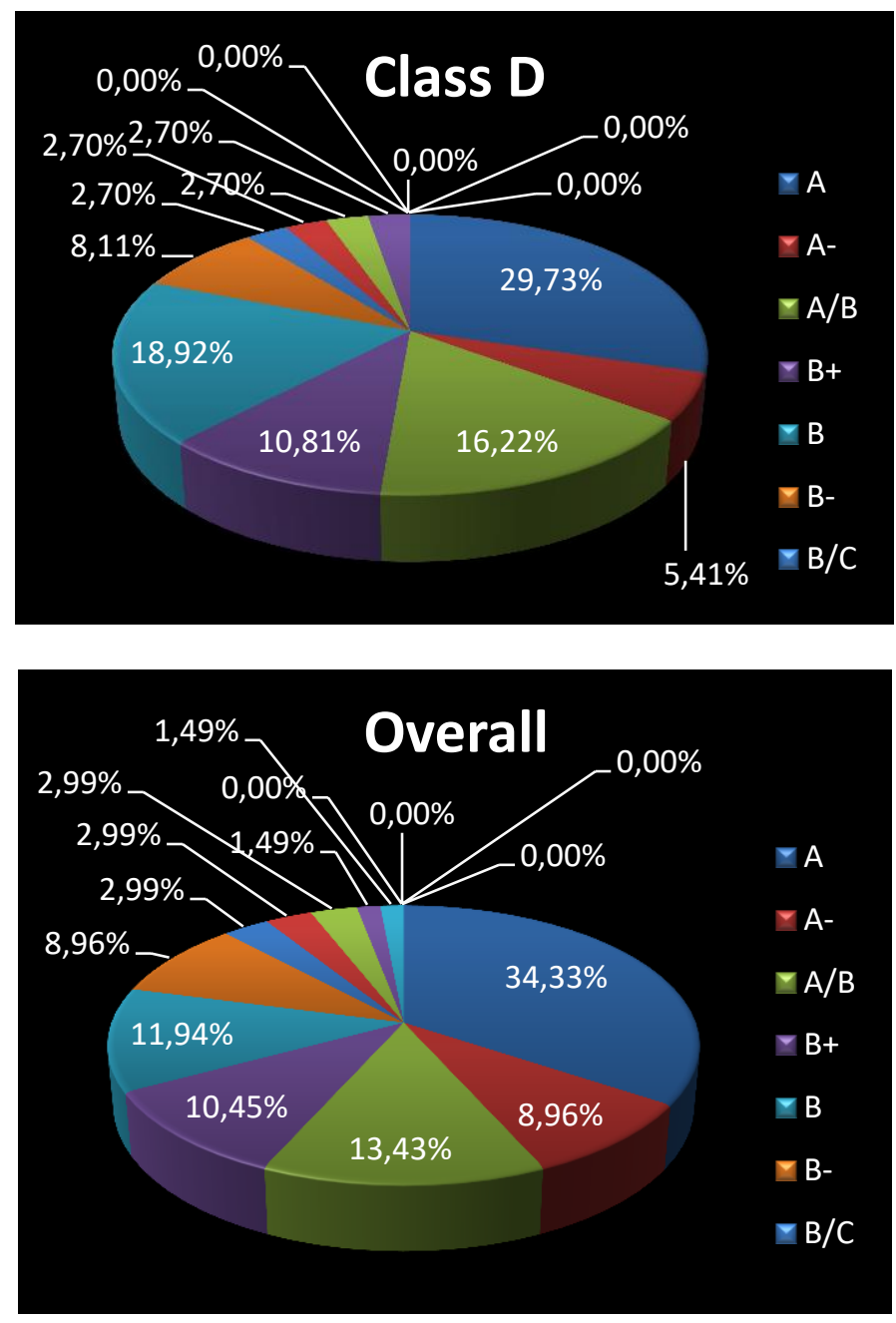

Figure 6. Final result of students

Figure 6 shows the percentage of student's final result for class A and class $\mathrm{D}$. The highest value in class A is A with a percentage of $40 \%$ and the lowest is $\mathrm{C} / \mathrm{D}$ with $3.33 \%$. While the highest grade in the class $\mathrm{D}$ is $\mathrm{A}$ with a percentage of $29.73 \%$ and the lowest was $\mathrm{C}$ with a percentage of $2.7 \%$. In total, for both classes, the highest value is A with a percentage of the acquisition of $34.33 \%$ and the lowest is $\mathrm{C} / \mathrm{D}$ with a percentage of $1.49 \%$.

If it is compared with the previous five years, where it was previously did not use RBL method, the average of final grades of students in the course Introduction to Stochastic Processes as shown in Figure 7 


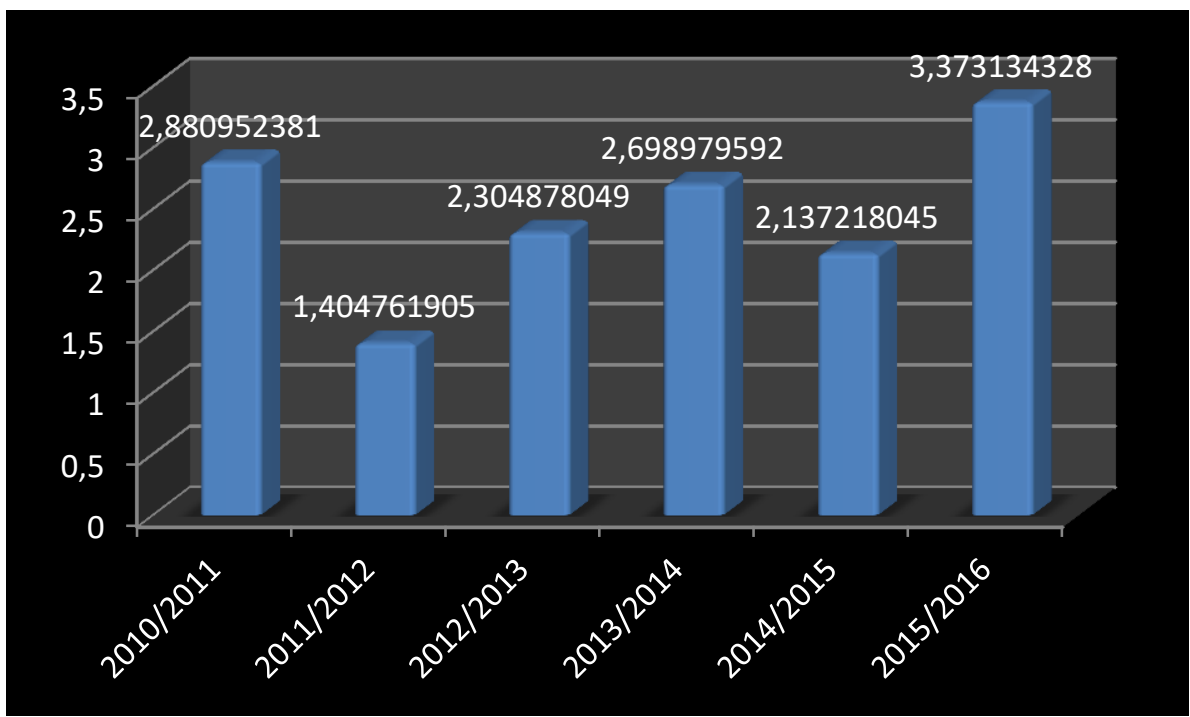

Figure 7. The average of final grades of students in the last 6 years

Based on Figure 7, it can be seen that there is a significant increase for the average of final grades of students with RBL learning methods compared to conventional methods. Over the past five years, average final grades of students never reach the scale of 3 out of 4 , but by using RBL method, the students final grades reach 3.3 scale out of 4 .

In addition to assessment of student learning outcomes, the assessment of the quality and interest in RBL learning methods can be seen from the results of student assessment evaluation form. The result of the calculation of the evaluation form shown by Table 10

Table 10. Assessment of Student with Form Evaluation

A. Material and Media Lectures

1. Suitability of the material with the planning

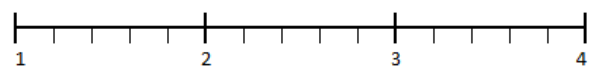

2. Material lectures help students to develop skill of critical and analytical thinking of the scientific fields related to probability theory

3. Students interested in conducting research using the course material has been taught
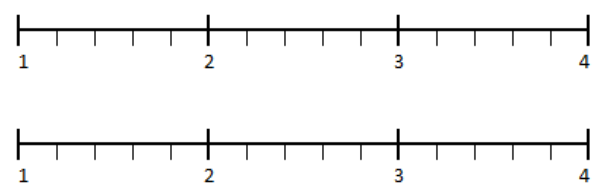

4. Students get lectures and examples of materials research easily

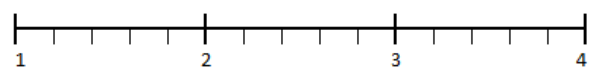


B. Course Lecturer

1. Punctuality of lecturers in teaching

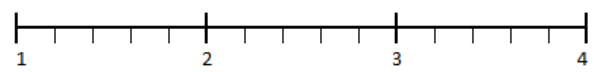

2. Readiness and clarity of the lecturers in teaching

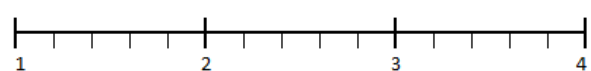

3. Mastery of the lecturers to lecture the material being taught

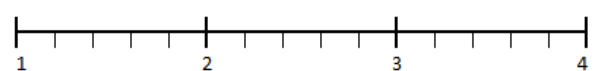

4. Willingness of the lecturers in serving questions or comments of students

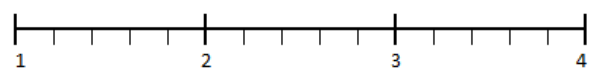

C. Implementation of the Learning Program

1. Lectures program (provision of material and execution of research) provide comfortable and attractive learning environment for students

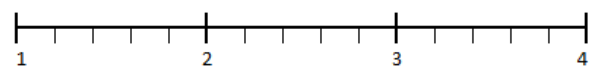

2. Students are satisfied with the learning program

3. Students are able to explore problems to a research related to the course being taught

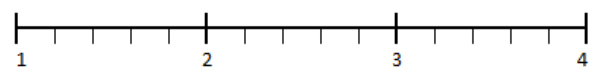

4. Students are able to determine the best method of issues that have been excavated
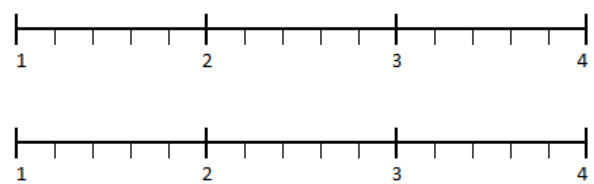

5. Benefits of discussion in the lecture to the student's understanding of the lecture material and research assignments

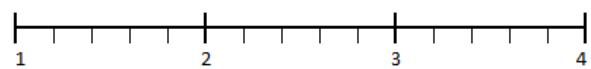

\section{Evaluation System}

1. Suitability of the assignments and exams with the lecture material

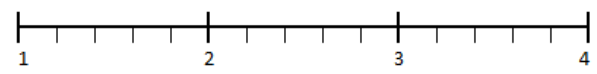

2. Suitability of the percentage of each component of the assessment to the work load assignments, exams, and research

3. The basis for assigning value and objectivity of lecturers in the assessments
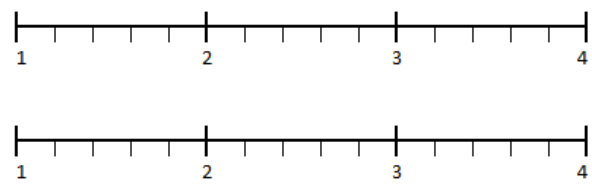

4. Clarity of the questions in assignments, tests, and an explanation for doing research

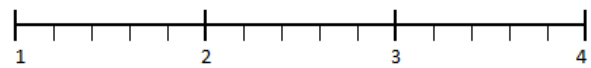

5. The estimated mark to be obtained for this course

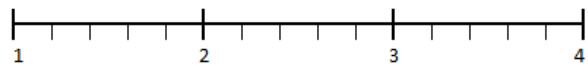

From the overall assessment of the students through evaluation form, the value is above scale 3 to all items of questions except for question 4 Section $\mathrm{A}$ and question 4 Section C. If it is being identified, an assessment of the ease of access to the course material and research constrained in less active students to find literature research because they are not familiar yet with the literature review. As for the lecture materials can be accessed easily through the lecturer's 
personal website. If it is summarized as a whole, the average scale obtained for each part of the assessment is as follows:

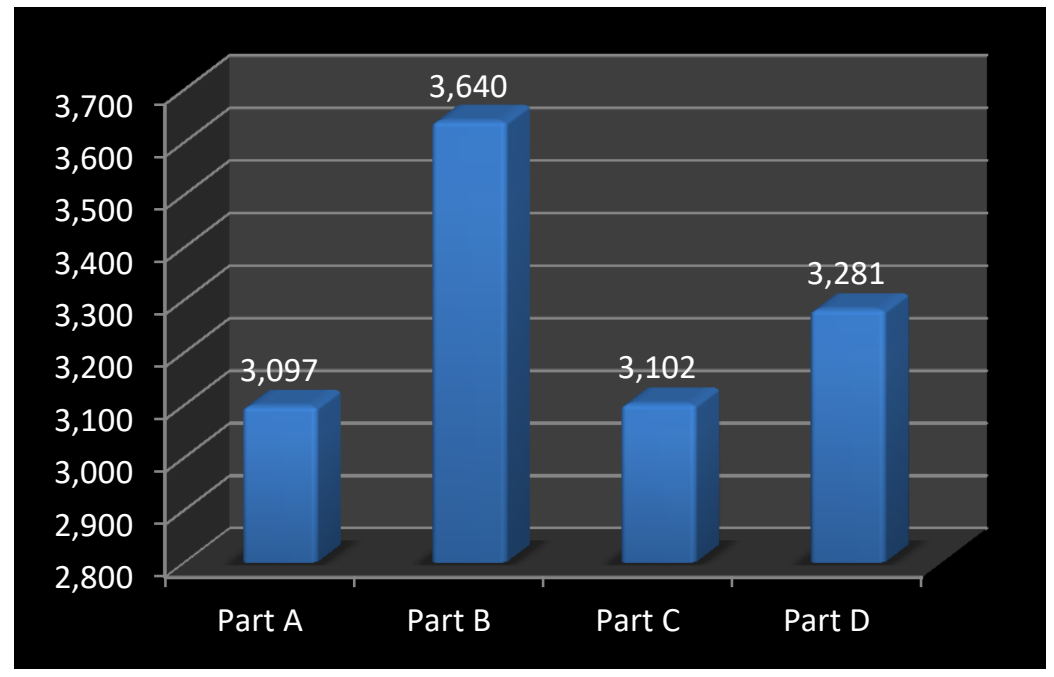

Figure 8. Average student assessment results for each component

From Figure 8, we can see that the student assessment of lecturer's ability of the course in implementing the lecture system has the highest score with a scale of values 3.640 , followed by an assessment of the scoring system with a scale of value 3.281, then the assessment of the implementation of the program of lectures with a scale of value 3.102, and the last is the assessment of the material and media lectures with a scale of value 3.097 out of 4 . From 59 students, then it has been calculated how many students who filled out the score in above scale 3 for each component of the assessment to obtain the percentage of the number of students who are satisfied and interested in this RBL learning program. The result of this calculation is as follows:
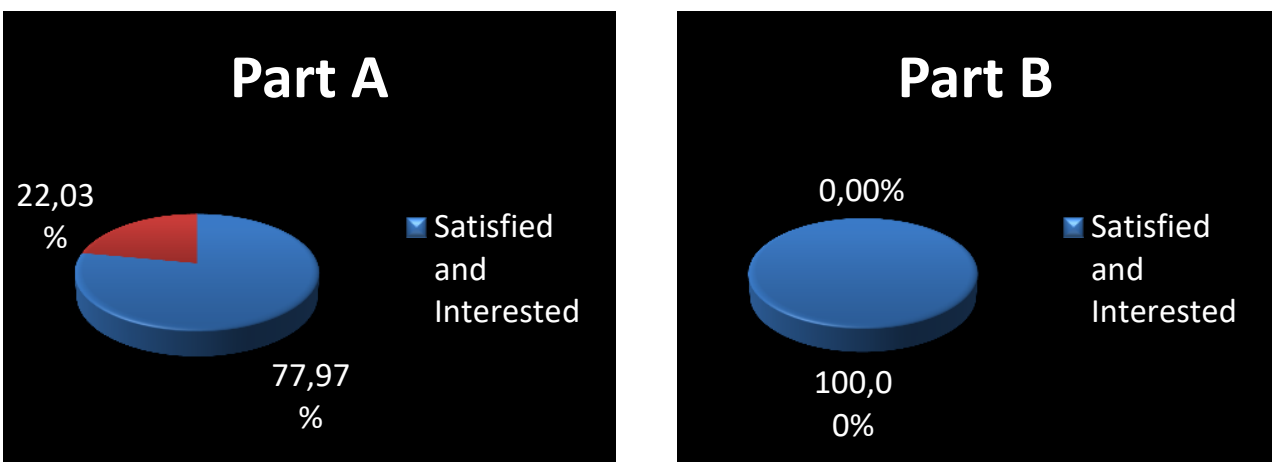

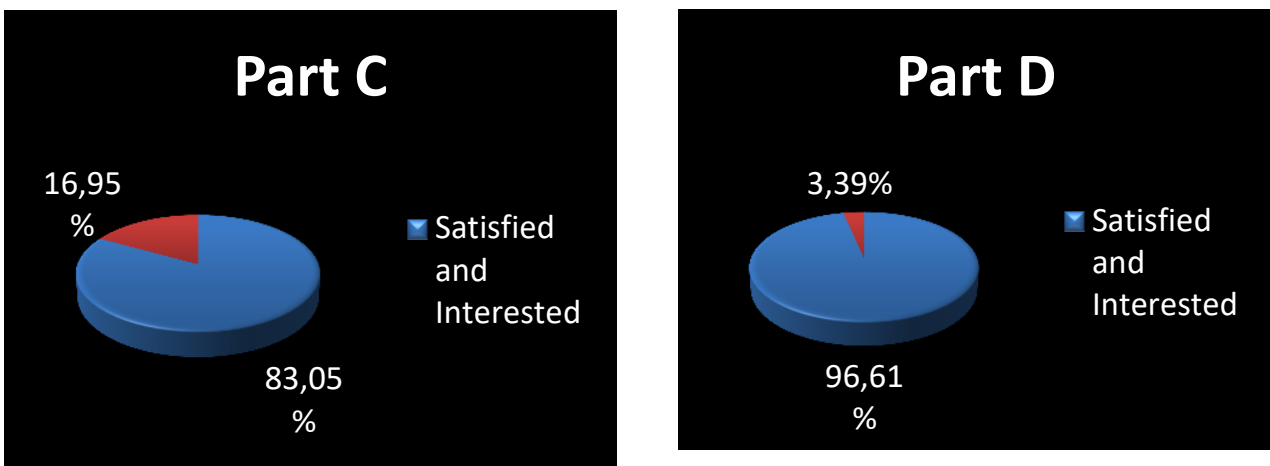

Figure 9. Percentage of students who are feel satisfied and interested in following rbl learning program for each part

Figure 9 shows the percentage of the number of students who are satisfied and interested in participating in RBL learning program. A total of $77.97 \%$ of the students are satisfied with the material and media lectures and $22.03 \%$ of the students feel less satisfied. To the satisfaction of the lecturers, $100 \%$ of students were satisfied. Furthermore, as much as $83.05 \%$ of students were satisfied and interested in the implementation of RBL learning program and as much as $16.95 \%$ of the students feel less satisfied and less interested. Recently, as many as $96.61 \%$ of the students are satisfied with the assessment system applied to the learning program and the remaining $3.39 \%$ of students feel less satisfied. Of the overall assessment, the average can be taken that as much as $89.41 \%$ of students were satisfied and interested in the whole range of RBL learning program in the course Introduction to Stochastic Processes.

In addition to the overall results of the assessment above, we have selected two best student articles that are currently being submitted to an international conference. Two of the best researchs are entitled:

1. Comparison of the Performance of Inpatient Care for Chemotherapy Patients in RSUP Dr. Hasan Sadikin Bandung West Java Using Queuing Theory

2. Performance Evaluation of Services in DKI Jakarta Fire Department Using M/M/1 Queue Model

In general, here are the gains of RBL learning program based on performance indicators that have been defined before. 
Table 11. Summary of Performance Achievement of the Program

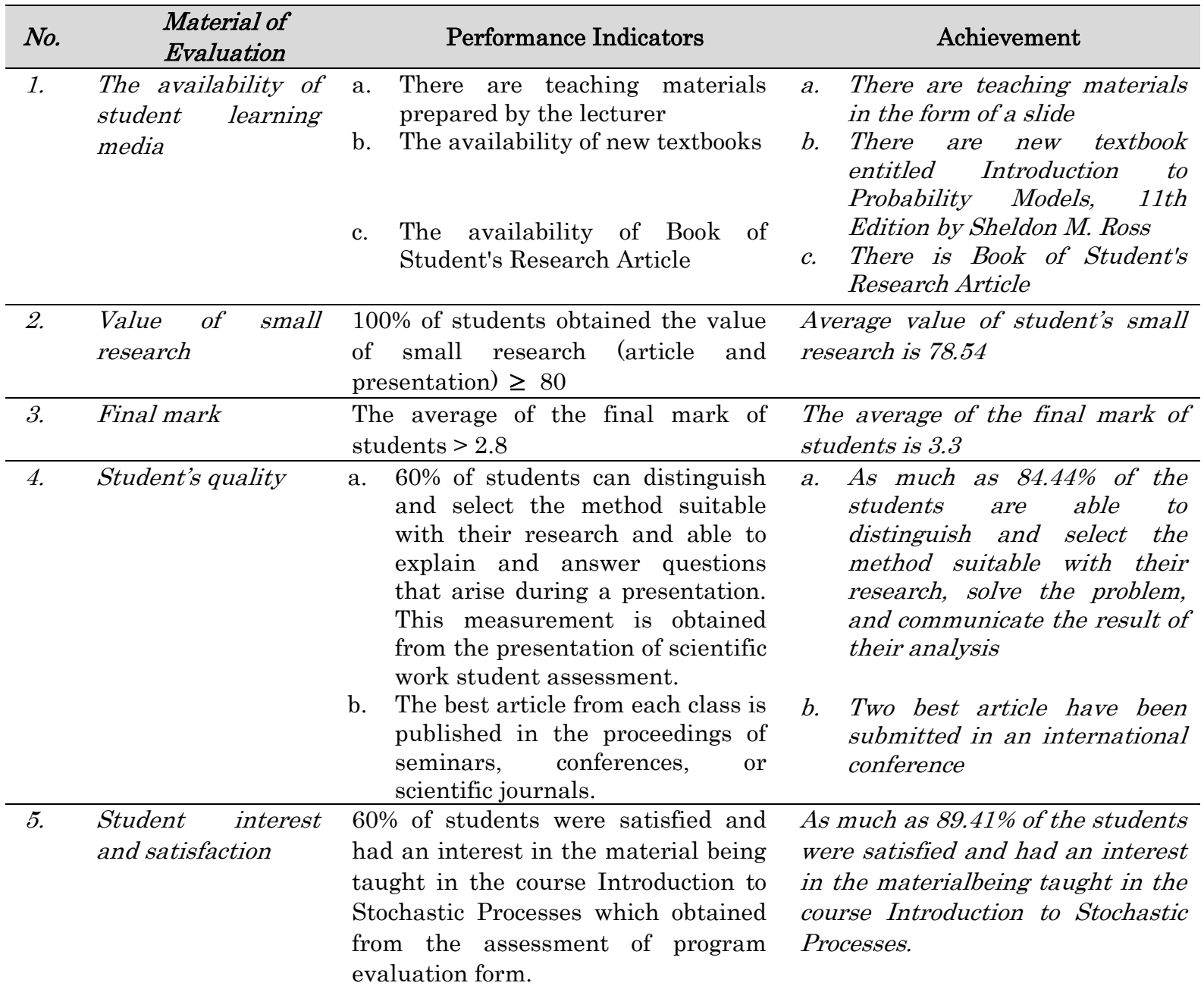

From the author's observation as a lecturers, here are some positive things that can be learned from the implementation of this research-based learning program:

1. Students can learn to explore a problem, choose the appropriate method, solve these problems, and communicate their analysis in the article form. So that students can practice critical and analytical thinking to problems that arise in real life and solve the problems by using statistical tools, in particular, stochastic methods.

2. Students understand the application and the use of stochastic methods to solve the problems in the real life.

3. Students can discuss research issues related to stochastic methods

4. The learning outcomes of students showed significant differences compared to when using conventional teaching methods.

5. The level of satisfaction and student interest in following the course Introduction to Stochastic Processes is quite high. 
Then, the following are a few notes that can be used as a media of implementing improvements to the course ahead:

1. The average value of the research student has not reached 80 , the results of the author identification are as follows:

a. The research duration is quite short, that is just about 2 to 3 weeks

b. Writing skill of students is needed to be improved

2. There are students in the group who are less active in conducting research and consult with lecturer about their research.

3. Students is not active yet in accessing the information about research issues

\section{Conclusion}

From the results of the implementation of research-based learning programs that have been implemented, the following conclusions can be drawn:

1. Application of the RBL method in the course Introduction to Stochastic Processes can significantly improve student achievement than conventional methods.

2. The practices of research done by the students in general were able to train students to think critically and analytically about the problems that occured in the lives around and be able to associate it with the use of stochastic methods to solve these problems.

3. Research-based learning programs generally provide satisfaction and student interest in following the course Introduction to Stochastic Processes.

As a further development of the program, the research can be developed by providing another innovation to complement the shortcomings of this study, for example held a workshop/talk show on tips of doing fun research by bringing in speakers from certain research institutes.

\section{Acknowledgement}

A sincere gratitude goes to the Academic Development Board of Universitas Islam Indonesia who has given financial assistance of teaching grants so that the program can run smoothly.

\section{Disclosure statement}

No potential conflict of interest was reported by the authors.

\section{Notes on contributors}

Atina Ahdika is a lecturer at Department of Statistics, Universitas Islam Indonesia, Yogyakarta, Indonesia.

\section{References}

Arends, R.I. 2008. Learning to Teach. Translated by Helly Prayitno and Sri Mulyantini Soetjipto. Yogyakarta: Pustaka Pelajar.

A., Safryadi, S., M. Ali, and Nurmaliah, Cut. 2013. Upaya Peningkatan Hasil Belajar Kognitif Melalui Model Problem Based Learning. Jurnal Biotik, ISSN: 2337-9812, Vol. 1, No. 2, Ed. September 2013, page $67-136$. 
Duron, R., Limbach, B., and Waugh, W. 2006. Critical Thinking Framework for Any Discipline. International Journal of Teaching and Learning in Higher Education (IJTHLE), ISSN: 1812-9129, 2006, Volume 17, Number 2, 160 - 166.

Eberly Center for Teaching Excellence. 2007. Theory and Research-based Principles of Learning. Carnegie Mellon University.

Ganio, Lisa M. 2010. Teaching Critical Thinking (in Statistics) for Natural Resource Education.

Green, Alison. Griffith Institute for Higher Education (GIHE), Good Practice Guide on Research-Based Learning. Griffith University. www.griffith.edu.au/gihe

Hafsah. 2015. Implementasi Riset Based Learning dalam Upaya Peningkatan Kualitas Pembelajaran. Prosiding SNEMA-2015, Padang Indonesia, ISBN: 978-602-17129-5-5, hal. $496-504$.

Hair, J.F., Black, W.C., Babin, B.J., \& Anderson, R.E. 2010. Multivariate Data Analysis. Seventh Edition. Prentice Hall, Upper Saddle River, New Jersey.

Healey, Mick, Jenkins, Alan, \& Lea, John. 2014. Developing Research-Based Curricula in College-Based Higher Education. New York: The Higher Education Academy.

Muhson, Ali. 2009. Peningkatan Minat Belajar dan Pemahaman Mahasiswa Melalui Penerapan Problem-Based Learning. Jurnal Kependidikan, Vol.39, No. 2, Nov. 2009, page $171-182$

Ross, Sheldon M. 2007. Introduction to Probability Models; 9th Edition. New York: Academic Press.

Tremp, Peter. 2010. Research-based Teaching and Learning; A LERU project. Universitat Zurich.

Widayati, Diah Tri, et al. 2010. Pedoman Umum Pembelajaran Berbasis Riset (PUPBR). Yogyakarta: Universitas Gadjah Mada. 